\title{
THE WALLING OF DHATUSENA
}

Despite the singular manner in which it presents its history, intermixing facts that are supported by epigraphic and monumental evidence with what is presented through myth and fantasy, Sri Lanka stands out as one of the few ancient civilizations that can pride itself on a recorded history $a b$ urbe condita. The Mahavamsa reaches even further back, recording the origin and development of Buddhism in India before its passage to the island, whose people, tradition asserts, were destined to preserve the teachings of the Buddha in their pristine purity.

From the point of view of political science, however, this long and continuous history of over two thousand years before foreign intervention from the West, has little or nothing to give the world beyond a monotonous concatenation of monarchies constituting one of the longest on record anywhere.

At best, these range from benevolent rule to blatant tyranny, with hardly any record of agitation to replace it with some other form of government, whether aristocratic or senatorial, from the notables, or some manner of democratic governance in which the hoi polloi had some participation in ruling themselves. Nor is there so much as a record of popular agitation for any of those "freedoms" or "human rights" that even extreme dictatorships have at times been constrained to concede.

On the other hand, monarchy seems to have been accepted over the years as the single form of governance for men (as it was for ants!) to live under, with whatever human freedom (if we may call the semblance of such) as may have been observed, those enjoyed under weak rulers or crumbs swept down to the masses of the monarchical table by this or that ruler.

If then there is any institution the chronicle, as it stands, makes it worthwhile to study from the point of political history, it may be that of hereditary kingship, its powers and privileges, functions and obligations-not to mention the vicissitudes of succession which range from ethnic to dynastic, quirks of fate to force of arms, court conspiracies, murder by sword or poison - even an instance, if we may believe it-of downright tomfoolery!

However, all this is not for me-not here or anywhere else. What I wish to do with this piece of writing is no more than express my opinion-as I did with the Subha-Yasa affair - on the historical narrative of the Culavamsa which tells of the remarkable

\footnotetext{
'The Sri Lanka Journal of the Humanities vol. xxxvi nos. 1 and 2(1910) p. $1-9$.
} The Sri Lanka Journal of the Humanities XXXVII (1\&2) 2011 
circumstances in which the rule of one of the kings of antiquity is said to have passed to his successor-here too by a most interesting domestic drama not unknown among other nations, but which, in the instance to which I refer, appears to have been somewhat miscomprehended due to the reading of the Pali in which it had come down to us.

What I advert to, as the title of this review may give one to understand, is that mode of killing adopted by the senapathi, Migara, for carrying out the order of Kassapa to kill his father, Dathusena, in such a way as not to incur the guilt of shedding kindred blood.

If, in the course of this, I make my observations on other aspects of the story, or on others' observations thereof, I believe they will be of some relevance in the broader study of this domestic episode which results in the usurpation by the elder brother of the succession intended for the younger, leaving the island with that remarkable monument of his psychic insecurity, if not his megalomania-that rock fortress of Sigiriya.

Walling, known in antiquity in some countries of South-East Europe but also in certain other countries elsewhere in the world, appears to have been restored to with a view to securing the death of the victim as if he has not been murdered but had died of his own, by confining him in a walled enclosure, be it a room, prison, or dungeon, and then walling off the entrance. Sometimes some food and drink was provided to let the victim live on for a time to give the impression that he was alive after being left behind. Death, when it happened, was due to starvation and dehydration-if the victim, suffering from claustrophobia, depression and deprivation in the darkness of the vault, had not somehow taken his own life.

The best-known example of such immurement in literature of course is that of Antigone in Sophocles' tragedy, Antigone ${ }^{2}$. Here Creon, king of Thebes, fearing the shedding of kindred blood, has his niece confined in a cave in a remote region of his kingdom. An exercise of like nature in real life had to be botched when the Spartan king, Pausanias, facing arrest for treason, ran into the temple of the Goddess of the Brazen House, and was walled off in it to die of his own - though he was dragged out at the last moment, fearing the temple being then polluted by his death in it ${ }^{3}$.

' vs 885 f. See Sophocles The Theban Plays transl. E. F. Watling (Penguin) p. 147:

Creon: "I'll have her taken to a desert place/Where no man ever walked, and there walled up/Inside a cave, alive with food enough/To acquit ourselves of blood-guiltiness/That else would lie upon our commonwealth."

See also p. 150

Creon: Away with her at once/ And close her up in her rock-vaulted tomb./leave her and let her die, if die she must,/ or live within her dungeon. Though on earth/Her life is ended from this day, her blood/ Will not be on our hands.

${ }^{3}$ Thucydides The Peloponnesian War transl. Rex Warner 1954 (Penguin ed.) p. $87 \mathrm{f}$. "He then took to flight and escaped them (the Ephors) by running to the temple of the Goddess of the Brazen House, the precinct of which was quite close. There, so that he should not suffer from exposure to the weather, he found a small room inside the temple and stayed in it without making a sign of his presence. For the time being the Ephors had been left behind in their pursuit of him. but they afterwards removed the roof of the room, and having made sure that he was caught inside, they walled up the doors, having sentries around the place, and proceeded to starve him out. When they found that he was on the point of dying, just as he was, in the room, they brought him out of the temple while he was still just breathing, and as soon as he was brought out, he died." 
A classic account of the process of walling comes to us from Plutarch ${ }^{4}$ as follows, when he describes it as the mode of death reserved for Vestal Virgins guilty of violating their vows of chastity, as instituted along with the office during the reign of king Numa:

She that has broken her vow of chastity is buried alive near the Colline gate. Here a little ridge of earth extends for some distance along the inside of the city wall. The Latin word for it is agger. Under it a small chamber is constructed with steps leading down from above. In this are placed a couch with a covering, a lighted lamp and very small portions of the necessities of life, such as bread, a bowl of water, milk and oil, as though they would absolve themselves from the charge of destroying, (even) by hunger a life which had been consecrated to the highest services of religion.

After the victim had been carried in a covered litter through the forum, she is brought to the steps leading down to the chamber.

Thereupon the priest (who officiates at the ritual) turns away his face, as do the rest of the priests, and when she has gone down, the steps are taken up and great quantities of earth are thrown into the entrance of the chamber, hiding it away and making the place level with the rest of the mound. Such is the punishment to those who break their vow of virginity.

Walling of a person was restored to upon the inauguration of any considerable edifice or project in the belief that it would facilitate the work, protect the workers and assure the strength and security of the edifice. It seems that, with or without his consent, he was bonded into the edifice and believed to fiercely give it his protection.

I have my doubts, however, whether the process of walling, instead of the offer of a sacrifice (billa) per se, had ought to do with the unearthing of treasure, as Gananath

${ }^{4}$ Life of Numa x.4-5 
Obeysekere, in his article, "The Sacrifice of Dhatusena: History as Story-telling and Story -telling as History" ".5 had presumed.

The account of the circumstances, which led to the death of Dhatusena follows upon a record of the great services rendered by the king, both for his subjects and for the religion. These included as much as eighteen great reservoirs (one of them, the Kalawewa) and eighteen viharas in the course of the reign - as reiterated by the Pujavaliya, Rajavaliva and Rajarathnavaliya - of also eighteen years, the result of which is that the chronicle lists him among the ten excellent rulers who held sway during this period.

I give here Geiger's translation of the Pali of the circumstances which led to this death, as given by the Cularamsa:

Dhatusena had two sons, Kassapa by a mother of unequal birth and the mighty Moggallana by a mother of equal caste, also a charming daughter who was dear to him as his life. On his sister's son he bestowed the dignity of senapati and gave him his daughter (to wife). Without blame (on her part) he struck her with his whip on her thigh. When the king saw the blood-stained garment of his daughter and heard of the affair, he in his wrath had his nephew's mother burnt naked. From this time onwards the nephew nursed hatred (against the king), joined Kassapa, awoke in him the desire for royal dignity, estranged him from his father, won over his subjects and took the ruler (Dathusena) prisoner alive. Thereupon Kassapa raised the umbrella of dominion and destroyed the people who sided with his father, having every scoundrel as his comrade.

The Culavamsa (38.115) shows an overall appreciation of Dhatusena, listing him among the ten excellent monarchs of this period, no doubt in consideration of the large amount of work he had done for his subjects and the religion during the relatively brief period of this reign. Yet, the nature of his crime, the stripping of the senapati's mother in public and then burning her alive is an indescribably cruel deed, for which he deserves what the senapati meted out to him-- and this too, strangely, when he did nothing to the senapati himself who had whipped his daughter to bleed - not even deprived him of his post of senapati in which he could and did, avenge his mother. Besides, as Geiger reminds us with a footnote ad $10 c^{7}$, was not his daughter's mother-in-law his own sister?

\footnotetext{
'Ariya Rajakaruna Upahara Lipi Sungrahay a Colombo (2004) p. 569-591. I was already deep into the question of the Dhatusena walling when my attention was drawn by this fascinating and equally provocative article of Gananath Obeysekere, eminent sociologist and long-standing friend. We both belonged, with Rajakaruna, to the first undergraduate batch of the University of Peradeniya.

"The Culavamsa, Being the Most Recent Part of Mahavamsa part I translated by Wilhelm Geiger. and from the German into English by Mrs. C. Mabel Richmers, Colombo (1953). p. 38 ch.38.80-87

${ }^{7}$ See 38.81 and Geiger's n.5 ad loc.
} 
Mary Museus Higgins ${ }^{8}$, who finds the king's deed too shocking even for narration to the young girls who were her listeners, yet is constrained to do so because it was, one way or another, responsible for his own death and suspects a mother-in-law/daughter-inlaw issue in which the king may have found culpability lay with the former for the beating the daughter he loved so much took from her husband.

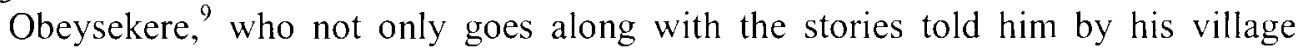
raconteurs, dignifying their version of things with the designation of "folk texts", takes them as good enough to bend any element in the Mahavamsa story to accord with his "prejudices" assumes that some people (?) including Migara (our senapati), "felt there was blame on her part which the Mahavamsa wanted to deny", then goes on to add. "I inferred from a commonsense point-of-view that this must be adultery".

His "folk texts"--there is no knowing when or where they had had their origins"not only further develop the story to the effect that her affair had been with a palace official and how it was found out". "Some folk stories", Obeysekere goes on to add, "Say that Migara's wife's offence was a trivial one which, he then observes parenthetically", "may be one way of defining adultery". And this, as I see it, is just what he has done here.

However guilty or not guilty the mother-in-law may have been in the matter of her daughter-in-law who has made a cuckold of her son, the humiliation of being stripped naked in public and the suffering she must have undergone, being burnt to death, would have been enough to make any mother's son mad at the perpetrator. And so indeed was this mother's son, Migara, our senapati.

Therefore, not content with having Dathusena deposed and imprisoned in a dungeon (bhandanagāranivāsena) he continues to instigate Kassapa, alleging Dhatusena had a hidden treasure he was keeping for Moggallana. Kassapa's attempt to learn where this was hidden was repeatedly met with silence, Dhatusena suspecting this was no more than a pretext to kill him. Finally, seeing here a good opportunity to meet there Mahanama, under whom he had studied when a monk--that, and to bathe in his beloved Kalawewa yet once more, he agreed to show the place where the treasure was concealed, if he were conducted to the region where the reservoir was. Thereupon Kassapa, happy at the prospect

\footnotetext{
${ }^{8}$ Stories from the History of Ceylon, Part I and ii, New Delhi (2003) (first published 1909) p.248250. King Dhatusena's Cruel Death.

"For "hidden discourse" brought to the surface or reinforced by "folk texts", which then go to support his "prejudices", see p.576.
} 
of laying his hands on the treasure at last, sent him a chariot with charioteer and messengers (guards?).

At this point, the Pali raises some problems of reading which need clarification if we are to get a proper idea of what followed. For here, L.C.Wijesinha ${ }^{11}$ reads it to mean that the king proceeded on the journey "with eyes sunk in grief". This is acceptable if it is applied to Dhatusena, who had lived in prison, awaiting the inevitable but perhaps kept alive by Kassapa in the hope of obtaining the imagined treasure. Turnour " , however, had taken this to translate that the chariot sent to take him along had broken wheels. Geiger ${ }^{12}$, keeping with Turnour and the closeness he saw between the Pali akkhi of jinnena-m-akkhina to the Latin axis = "axle" is for reading the word to mean "with a damaged axle".

I cannot see what the point of this is. If Kassapa intended Dhatusena to be involved in an accident and die, he would not have been able to lay his hands on the treasure--he would have killed the proverbial goose that was to lay the golden egg. Still, as this is the better reading of the text, we may take it that it was intended to humiliate Dhatusena, used to the best of comforts when in power, by providing him with a ramshackle vehicle (Higgins: "a broken-down chariot") $)^{13}$ and a bumpy ride, what else? For nothing of the kind happened to Dhatusena as when Pelops in the Greek myth had Myrtilus extract the axle-pin from Oenomaus' chariot, killing him and leaving Oenomaus to take Hippodameia as his bride.

Having got to the region without incident except for the charioteer expressing his loyalty to the old king by sharing his meal with him (in appreciation of which Dhatusena gives him a letter requesting Moggallana to make him doorkeeper if and when he becomes king), Dhatusena takes a break with his onetime teacher, the monk, Mahanama, sharing the consolations of the dhamma and the pleasure of bean and chicken soup, his favourite, then proceeds to the Kalawewa reservoir. It is here that, after drinking of its water and bathing in it, he shocks his guards, declaring that this reservoir, the Kalawewa, was all the treasure he possessed.

When, upon returning to the city, this was reported to Kassapa, he was furious, and thinking his father was keeping the wealth hidden for Moggallana, ordered his senapati to have him executed. Thereupon, we are told, the senapati, in full regalia of his office, and strutting before the old king, tried to provoke him to anger but failed, his response being that he had harboured the same feelings for his nephew, the senapati, as he had for Moggallana, his son. To this, the senapati's reaction was no more than a sarcastic laugh-whereupon he realised he was going to be killed.

Then follows the tersest of descriptions of the strange manner by which he was put to death, about which it would have been of interest if the chronicle had been a little more expansive, considering that its borders on that well-known practice resorted to by killers fearing pollution by the shedding of kindred blood--walling, to which we have already

${ }^{10}$ The Maharamsa Part II containing chapter xxxix to c translated from the original Pali into English for the Government of Ceylon, Colombo (1909) Pali; jinnena-m-akkhina.

"George Turnour, transl. The Mahavamsa in Two Parts with notes and elucidations by L.C.Wijesinha, p. 259 vs. 94-95.

12 op.cit. p.39 n.2 ad loc.

13 op.cit. p. 249. 
adverted and which is my chief concern in this study. The Pali descriptive of this, a propos Dhatusena, which is hardly more than a two and a half lines, reads as follows ${ }^{14}$.

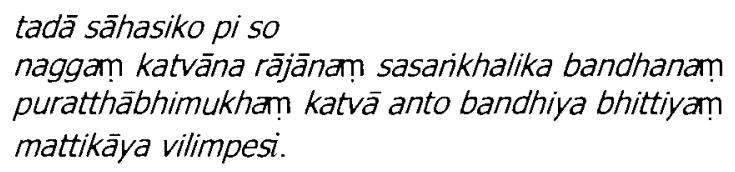

Turnour's English translation of this account reads as follows ${ }^{15}$ :

(The usurper) then stripping the king naked, and casting him into iron chains, built a wall, embedding him in it, exposing his face only to the east, and plastered the wall over with clay.

The words italicised above constitute that part of the translation with which L.C. Wijesinha is not in agreement. His own translation of the Pali, with which he had tested Turnour, then goes as follows: ${ }^{16}$

Then this violent man stripped the king naked and bound him with chains inside the wall of his prison with his face to the east, and caused it to be plastered up with clay.

It is to be noted that while Turnour took the wall to have been built incorporating the king, (there being no wall before), Wijesinha presumes a wall already there, which he takes to be of the prison, boldly stating in parenthesis "of the prison"--meaning that dungeon or vault in which Dhatusena had been held prisoner since his arrest by the senapati on the orders of Kassapa, plastering of clay then not being of Dhatusena against the wall to which he had been chained and fettered, facing east, but of "it", by "it" Wijesinha quite clearly meaning the prison door.

This, then, is a typical instance of walling as applied to a kinsman-his father no less, out of the fear of shedding kindred blood - except that in addition our prisoner is

\footnotetext{
${ }^{14}$ Cul.38.109-111.

15 op.cit. p.259 ad loc.

16 op.cit. p. 259 ad loc.
} 
chained to the wall rigid, perhaps like Prometheus to the Caucasian crag, or with the ability to move his limbs around. (Despite this, however, as we see afterwards, the stigma of parricide and his guilt over it never left him, nor was it taken to have left him, whether by clergy or laity, until the day he ended his own life by suicide).

Geiger ${ }^{17}$, for Wijesinha's taking "inside the wall" to mean the side within the prison (anto bhandhiya bhitthiam), read that Dhathusena was embedded or inserted into the wall, as Turnour did, but being unable to identify what this wall is, takes it to imply a niche in some wall or other, into which Dhatusena was inserted and affixed before it was daubed with clay-all except the head, giving rise to the now popular notion of how the old king was walled. Accordingly, he translates:

Thereupon the brutal (senapati) stripped the king naked, bound him with chains and fetters in a niche in the wall [Geiger footnotes "Lit. in the inside of the wall'] with his face outward and closed it up with clay.

On two separate occasions, when communicating with Dr. Raja de Silva (onetime Commissioner of Archaeology, whose interest in Sigiriya is all too well known), I expressed my notion that if Dhatusena had to be clayed in such a niche, there was need to hold him immobile in it thereafter; one shake of his body and the clay would have been dislodged. There was no need to do so within the prison or dungeon since what was clayed was the door leading into it. I believe his Zen silence meant that the chains and fetters implied this as well.

Geiger changes head facing east to head facing forwards for the victim to watch what was being done to him; he sees no reason why he should face east. Nor does anyone else of the translators. But then, one could face east and also forwards at the same time if the wall stretches from north to south? The more important thing would have been the leaving of the head un-plastered with clay, if the intention was to allow him to die of starvation and other causes except suffocation, much like a face-unwrapped Egyptian mummy in a coffin placed vertically.

Indeed, at some time I thought the image of our king in his niche in the wall, all the rest of him roughly plastered except the face, may have been suggested by one of those sculptures of stone or stucco, even one begun in his time, which had been abandoned halffinished due to one reason or another, with the details still to be worked upon it. As is evident, I am not with this idea of the walling anymore.

As he translates then, Geiger is constrained to interfere with a perfectly acceptable word (puratthäbhimukham), even if the intention eludes us, and import an idea that nay not have been in the chronicle (viz. that of a niche). The Sinhala translation by Sumangala and Batuwantudawe is not of much help either, with their ambiguous athulu bitthi benda for what was done to the king along with negenahirata muhunala. I am therefore inclined to go along with Wijesinha that the wall concerned-and there surely was one that, chained to it, the prisoner could still face east - was of the prison or dungeon, and along with it, the claving was of its door: not of the prisoner.

W.A. Jayewardena appears then to have done much thinking in respect to the Pali when he followed Wijesinha rather than Geiger and, in The University of Ceylon, History 
of Ceylon ${ }^{18}$, in which he treated the history of the kings of this period, declares in no uncertain terms, that "the old king was imprisoned and later put to death, walled in a dungeon-referring surely to that same dungeon (bhandanagāranivāsa) in which he had been confined since his arrest by the parricide Kassapa ${ }^{19}$, by this device (as was the intention, even when sometimes some food and drink was provided) hoping to fool himself that the victim had died and was not killed - that there was no kindred blood on one's hands.

On the other hand, by the method of walling as visualized by the Geiger translation, the head had to remain exposed if the victim was to die with time and not immediately by suffocation--when this would have defeated such intention.

If, on the other hand, the intention was to watch the man die slowly in his clay coffin, once again the relieving of the perpetrator of the walling would be self-defeatingthe sadistic enjoyment of seeing his victim die in degrees would only incriminate him the more, perhaps also infuriate the populace. It must be remembered that we have here a son killing, for whatever reason and however angrily, his own father, incriminating himself in the terrible crime of parricide.

Notwithstanding the expectation, Kassapa appears to have suffered great mental agony afterwards and, keeping on asking, "How can I be saved?" (Cul. 39.8-19) did many meritorious deeds. But it appeared that both clergy and laity were chary of accepting gifts from the parricide they considered him to be, until in the end, worsted in conflict with his brother Moggallana, he was obliged to cut his own throat on the battlefield ${ }^{20}$.

\footnotetext{
Is vol. I pt. I Colombo (1959) p296 Obeysekere, facing up to the possibility of Dhatusena's walling being (for lack of a wall) of the palace, which might then have been thick enough for a niche, (I have not come across any historian doing so), answers the unlikelihood of this, considering ghosts-- here, more so his father's ghost. He answers Jayawardena's observation by merely disparaging it as inclined to a western or rationalist outlook (as he does now and again of opinions uncongenial to his point of view) calling it "an appropriate Europeanized home for a king bound with chains and fetters", when both dungeon and fetters belong with the Pali text as inflicted on Dhatusena. Geiger's suggestions of Dhatusena bcing made to watch his own punishment is "on the model of the Inquisition"(op. cit. p. 580), that great Indologist's reference to a "clod" of earth thrown at the monk in Cul.38.114 as intended to render as intelligible to his "western rationalist tradition". What is so westem about a clod? and was not the work going on on the bund using earth, clods or otherwise?

${ }^{14} \mathrm{Cul}$. 38.87-88. This source is the opinion (even if writing for children) of Higgins (loc.cit)

${ }^{20}$ Cul.39.24-28. See my Five Roral Suicides, SLJH vol, xxix (2003 -2004) p. 267-277.
} 
It is by no means an easy matter for historians to sift the facts that have undergone mythologizing with time and in that antiquity before finding their way into those compendia that supplied the chronicles. Now it looks as if we may be obliged to contend with a problem of a different nature-a crop of so-called "hidden discourses", thought to be in the knowledge of certain unsophisticated persons-in the case of our Dhatusena story, in and around Sigiriya-which have acquired a dubious respectability in certain disciplines as "field-texts", yet are totally unknown to the historical sources.

Obeysekere argues for the independent character of this tradition-as good for him, if not better, than what has been vouchsafed us in the chronicles, and reliable-as he confidently relies on them to interpret, supplement or otherwise revise the island's history as has come down through those traditional sources - this too, when his own informants confess to ignorance of their sources or at best can refer them to a generation or two of pure hearsay. To an imagined rebuke that the story told by one of his informant that, when Dhatusena put earth on the head of that meditating monk (which I take it the chronicle intended no more than to explain karmically the use of his clay in his walling) he was in fact burying him alive as a human sacrifice necessary for the inauguration of the Kalawewa bund, was no more than a folk gloss on the brief Mahawamsa reference ("for empiricist historiography tends to denigrate the oral tradition"), Obeysekere admits: "This is possible" - though he then seeks to establish the innocence of his sources with contentions which I regret I do not find as good as he thinks they are ${ }^{21}$.

1. The Mahawamsa, he says, is in Pali, whereas this region in which his researches were conducted-villages in the neighbourhood of the Sigiriya rock, even at the time of his visit (1989), had only a few literate monks around and it is not likely that they were literate in Pali. All monks, may I say, are literate-and several in Pali as well, in which all they recite and teach drew their original texts.

2. Besides, there is no need for one to be versed in Pali to be acquainted with the story on Dhatusena and Kassapa, which has come to us, who know it, mostly from history and Sinhala literature and it cannot be said that the people in these parts had not as children, attended schools. One of Obeysekere's informants, Kiri Banda of Kumbukkandawela, 50 years of age, was himself a school teacher ${ }^{22}$.

3. This also goes for the argument that there were no translations of the Mahawamsa freely available in Sinhala. One does not have to go to the original text or its translation into Sinhala for these they usually come to ordinary folk verbally or as disseminations from secondary sources, Sinhala Higgins' and Raven Harts.

4. Nor does one need to be or meet an archaeologist especially to get the kind of information that these folk texts have come up with, since they themselves claim their information comes from their older generation, not scholars or experts in history or archaeology.

5. In any case, it is surprising if Obeysekere says of these latter-day archaeologists, that they would have been unaware of the anecdote of Dhatusena and the meditating monk upon whose head he had earth put, if they were archaeologists of any worth. 
6. How could they not have had intimate knowledge, if not of the Pali, of even the translation for the information the Mahawamsa provides of the father whom that monarch killed, whose rock-fortress towered over the landscape, visible for miles around-and how could those indeed, school-child to grown up likewise, who lived in its shadow, have failed to know what there was to know about it?

7. As for the information from latter-day archaeologists, says Obeysekere- it is doubtful whether the villagers got their information from them since these archaeologists "could not possibly have been interested in exploring this very brief reference in the Mahawamsa". What!?-not interested in the Dhatusena-Kassapa story of the Mahawamsa when working in the region of Sigiriya? What a kind of archaeologist is he talking of"?

8. Besides, this had already been earmarked as a Cultural Triangle area when Obeysekere met his informants, and if an archaeologist working here on account of the paintings and graffiti or preservation and exploration had not known this story, whatever Obeysekere may call him, I have no word for him.

Obeysekere tries to convey the impression that Sigiriya and the region around it is backward, uneducated, "an isolated forest region". This is not quite so. Sigiriya, with Dambulla just a few miles away, is with Anuradhapura and Polonnaruwa, one of the most frequented tourist sites in the island. It was already so when I was myself District Land Officer in Polonnaruwa, covering the area with frequent visits to Kibissa, Ilukwewa, Kumbukkanoya etc. This was way back in 1958, thirty years before Obeysekere's visit and the growing influx of tourists, foreign and local, the coming of television, Cultural Triangle activity, the tourist-guides ${ }^{23}$, tourists, traders, taxi drivers and touts with their highly imaginative accounts of the historical happenings-all this and more, which, it is impossible, would not have their impact on these purveyors of historical fantasy.

If there is anything to wreck this bunch of texts on which Obeysekere relies for what I must say is a fascinating article, if only I can get myself to accept evidence of this

23 I am informed by a one-time Director of Tourism and still training guides etc, Nadani Panditaratna, that guides were given a good knowledge of the histories and archaeology of the sites to which tourists were taken which obviously included Sigiriya and its environs. It is possible some "improved" on what they learnt. 
nature-is his own admission of his sources' admission that they had heard this kind of story from "our fathers and their generation"-which Obeysekere is candid enough to confess of his story-telling as history as against the Mahawamsa's history as story-telling, "minimally from around the middle or early part of the last century", whereas the chronicle's recording, which they seek to annotate, interpolate or otherwise muck around with, dates back to beyond the Atthakatha which yields us this chapter of the Culavamisa.

It is probably to suggest the small quantity of earth scattered or poured or otherwise dumped on the monk's head on the orders of Dhatusena that Geiger had referred to it as a "clod". Likewise Sumangala and Batuwantudawe, in their Sinhala version (as translated into English by Obeysekere ${ }^{24}$ himself), has it that, unable to rouse him (the monk) from his trance, he, the king, got earth put over him. This is no more than what a monk had done to him, resorting to dung or refuse, for which all that Dhatusena did by way of revenge was to deny that monk's temple of royal gifts, once he became king. This, and the violence of the karmic reaction that was visited upon Dhatusena, more especially when there was already ample justice for his suffering what he suffered, is, as I said, my reason, was suspecting this incident at the tail-end of the story as some sort of gratuitous afterthought-even that this may have been introduced as late as when the chronicle itself was being put together.

Obeysekere however thinks that there is something suppressed from the story and counts himself fortunate to have had this made good by one of his field-historians, a personality called Battagurunnanse, described by him as a "priest", and again "specialist in the cult of planets and demons" ${ }^{25}$ - in my opinion, an accomplished humbug who made his living by coming up with spooky stories, causing fear and suspicion in his superstitious clientele and who, far from being trusted to set aright the Mahawamsa, would not stand two minutes cross-examination in the witness-box in a case of petty larceny. However, according to this man, when Kassapa was a young prince, King Dhatusena built the Kalawewa. He inaugurated the building of the bund by saying "Namo" and putting on the first shovel of earth, but he refused to offer a human sacrifice to Bahirava, the god of the underworld. He was thus building the reservoir bund without fear when he came across an arahant meditating there. The king was getting special machines to put earth on the bund, pata,pata,pata,pata-like and he thus buried the arahant under the earth. He had in effect-and not notwithstanding the "Namo", offered a human sacrifice, and he could now proceed with the building of the bund.

Perhaps there were those who were unhappy that Dhatusena underwent so terrible a death for throwing soil or refuse on a monk's head, for I find it as an extension in the translations of both Turnour and Wijesinha - though not in Geiger's Pali text or his translation thereof.

\footnotetext{
${ }^{24}$ Hikkaduwe Sri Sumangala and Don Andris de Silva Batuwantudawe Mahawamsa Sinhala transl. vol II $5^{\text {th }}$ ed. Colombo(1930) vs. 38-114.

25 Obeysekere, p.576-577.
} 
Turnour:

And not being able to rouse him from his abstraction, had him buried under the embankment (he was raising) by heaping earth over him

Wijesinha: (objecting to Tourner's words italicised above and allegedly comparing them with the Pali):

And because he could not rouse him therefrom, he caused the priest to be covered with earth (and so buried him)

There is no suggestion here of a human sacrifice for the successful building of the bund. Rather, the story is told for the use of the clay in the walling of Dhatusena, even if we are prepared to go along with the Turnour-Wijesinha extended reading ${ }^{26}$. Nor, it must be pointed out, does the Pali call him an arahant. He is here no more than a nondescript bhikku, and called so twice over in the relevant verses (Cul.38.113-115):

\section{Kālavāpim ayam rājāa gaṇhāpento samāhitam passitvā bhikkhum ekaṃ tu vuțthāpetum samādhito asakkonto khipäpesi pamsum bhikkhussa matthake samadiț̣iniko vipāko yam tassa kammassa dipito}

The fact that he is in Samadhi, as I learn, does not make him an arahant either; it only tells us of that kind of deep meditation in which the meditator is "lost to the world". The small quantity of earth dumped on him to rouse him rudely is not dumped on the head because the head is the centre of this trance-stuff, as Obeysekere jibes; but where better

\footnotetext{
${ }^{26}$ Rev. Muwatagama Gnananda, Head, Pali and Buddhist Studies, University of Peradeniya, whom I consulted on, the relevant Pali, thinks the dumping of earth on the monk's head may refer, if at all, to a temple that went under, as did some in the recent Mahaweli project. My thanks to him as well as to Rathna Handurukanda, who also helped clarify the sense of the Pali. Mihiri Liyanage, Postgraduate student reading Classics, and R. M. Ratnayaka Menike of the library of the University of Peradeniya who gave me of their time and effort in the writing of this article. To them, too, my thanks.
} 
could earth be angrily emptied on a person obstructing work then, seated on the ground and apparently disregarding the king's request, than on the head!?

It is probably to suggest the small quantity of earth scattered, poured or otherwise dumped on the monk's head on the orders of Dhatusena that Geiger has, as mentioned, referred to it as a clod. Likewise, Sumangala and Batuwanthudawe in their Sinhala version (as translated into English by Obeysekere himself) has it that "unable to rouse him (the monk) from his trance, he (the king) got earth put over him". This is less than what a monk had done to him, resorting to dung or refuse, for which all that Dhatusensa did by way of revenge was to deny that monk's temple of royal gifts once he became king.

This, and the violence of the karmic reaction that was visited upon Dhatusena, more especially when there already was ample justification for his suffering what he suffered is, as I said, my reason for suspecting this incident, tagged at the tail-end of the story, as some sort of gratuitous afterthought--even that this may have been introduced as late as when the chronicle itself was being put together.

There is, however, Obeysekere's wish to shift the context of the whole episode from a Buddhistic to a demonological one, and for that, from wherever' it took place to the Kalawewa bund-a bund, mind you, already built and in operation, so much so that Dhatusena had delightfully sported, drunk and bathed in the waters of the wewa. And here again he comes up with the requisite text to show - this time one Kiribanda (50 years) - a school teacher form near Sigiriya ${ }^{27}$. This person had heard (from God knows who) that while Mugalan was repairing the Kalawewa it started to break several times: "I am telling you this" he says, "as best as I know. When it broke thus, it was considered necessary to offer a human sacrifice. Now, Kassapa wasn't a son of a royal princess: that was Mugalan, Kassapa decided to complete the bund by burying his father."

Dhatusena, Obeysekere's evidence says, had as a Buddhist not wanted to offer a human sacrifice (to Bahirava) when inaugurating work on the Kalawewa bund. But, now, with the covering up of the monk, he had unwittingly done the needful-according to story teller Appuhamy of Talkote, defined as a good Buddhist himself ${ }^{28}$, even if now the pounding of the holy monk (upgraded, as we saw, to arahant), is pounded into the bund of elephants, not those infernal machines that went pata, pata, pata and of which unfortunately we know no more than of Ravana's flying machine, the "wooden peacock. ${ }^{29, "}$

Even so, the monk's death, we are told, proved unacceptable - for who can kill an arahant! So the debt to Bahirava still remains - the bund keeps leaking. But now, lo and behold, a remarkable billa is available to Kassapa -in a dramatic peripeteia (worthy of the Roman Seneca or a blood-chilling thriller of Edgar Allen Poe), his father, our very own Dhatusena! And he becomes the sacrifice he himself failed to make but which he thought

\footnotetext{
${ }^{27}$ Obeysekere, p. 582.

${ }^{28}$ Obeysekere, p.579.

29) See Obeysekere op.cit. p. 577. I cannot fathom what is meant when he says, "The machine that shovels earth on the bund is influenced by tractors and other machinery". Is it that in Dhatusena's time Sri Lanka had machinery the likes of present day earth-movers, tractors and bull-dozers? Obcysekere is not sceptical, for he adds that the Sinhalese tradition has texts of "wondrous machines". Not again. I hope, those "field-texts"! At any rate, there must be some garbling here, if modern machines are believed capable of influencing those of antiquity. According to Appuhamy of Talkote (p.574), however, the compressing was the work of our humble pachyderm (twice. p.579).
} 
he had fulfilled when he rammed that monk into the bund with those Battagurunnanse's machines, or, if you like, Appuhamy of Talkote's elephants.

One thing this story does explain, which none of the translations of the Pali had succeeded in doing - provided of course, one went along with the version of the story Obeysekere's source had supplied -is why our walled king was made to face east. It is, it tells us, so that he could look the west-facing demon king (et tu, O Bahirava?) straight in the eye!

If then these field-texts have been successful in complementing the Culavamsa story of Dhatusena and at the same time putting the record straight with what it is alleged to have suppressed or distorted due to its hidden agenda, the whole matter of the walling of Dhatusena (my only interest in this piece of study) is now become of a "bunding", not "walling", the stage-set undergoing a change from where-ever to Kalawewa, where, somewhere along the bund (perhaps right under the present road way where once we had sat for lunch), there stands the fossilized skeleton of His Royal Highness, King Dhatusena of Sigiriya, manacled and chained, skull turned eastwards and in a setting that, granted one swift peep and I would have been spared the effort of translating the Pali, researching the text and all these hours of composing this my long overdue obituary on the old monarch.

The role now sought to be given him thus is then of one who has been incorporated into the building of an edifice in the expectation of his giving it stability and strength. Folk belief had already associated such a role with a man called Kala, who loved this expanse of water and died, saving the reservoir that Dhatusena had made of it when it had threatened to breach, plugging the opening, not with his finger, like the Dutch boy the dyke, but with this whole body.

The story of Kala and his secret treasure ${ }^{30}$, the reservoir, must surely have originated within Dhatusena's great love of this work of his. There was, however, no actual

\footnotetext{
${ }^{30}$ On the story of Kala as heard in the region, see R. Ravenhart Ceylon: History in Stone Pannipitiya (2005: first published 1964)p. $53 \mathrm{f}$. On the bund of the Parakrama Samudra is a shrine of Minnerideyio (said to be Mahasen). Minister C.P.de Silva, a lover of the reservoir, was cremated at the climb to it, my brother Christopher Peris, then Irrigation Engineer, explaining to Minister Maitripala Senanayaka of the popular belief. It was C.P. de Silva's decision where to breach the bund when the reservoir threatened to flow over it in the Dec ' 58 flood that is said to have saved the area from a major disaster.
} 
treasure (nidhana) to be unearthed or otherwise acquired, for which an offering of a billa had to be made to Bahirava or whoever-the Kalawewa itself was the treasure. So that to suggest that Dhatusena was now in this role of a billa-and bathing to purify himself for it (even unknowingly), not only overdoes things but comes too late-the reservoir was already there and himself, "imperious Caesar dead and turned to clay" already exploited by Kassapa (pardon the misquote) "to block the holes through which the water flowed away".

The Dhatusena-Kassapa conflict is not over yet--here is still a round to go-and in this the Obeysekere field-text awards game, set and match to the old king.

This time evidence is from the 84 years old Kiribanda of Kalundawa village ${ }^{31}$, an ayurvedic physician who was somehow replete with knowledge of Dhatusena's earlier years, his amours with a Tamil woman (ethnic factor now replacing caste factor), from whom he had begotten the violent Kassapa (as expected) and his marriage to a Sinhala lady (properly done), from whom he begot the "mighty Moggallana"(again, as expected). What then the chronicle is here suspect of having suppressed-or rather, distorted-is the manner in which Kassapa met his Waterloo when the brothers confronted each other somewhere between Sigiriya and Anuradhapura. For this text now reveals that when Kassapa's troops deserted him, seeing him have his elephant veer, it was not because he espied a great stretch of swamp in front of him, as the Chronicle says ${ }^{32}$, but something far more dramatic. This was the appearance before his very eyes (like Banquo's ghost) of the horrible apparition of his dead father, "his head bent, broken, in front of him, like a shadow or an illusion"- an apparition that scared the living daylights out of him $^{33}$ and made him cut his throat, still seated on his elephant.

*

*

*

*

*

I have myself been interested in the mythic suspension in which the myth-historical passages of the Mahawamsa have come down to us, more especially of the earliest period when I found Greek material intermixed with it, while other scholars more learned than myself, like R.L. Basham, G.C. Mendis and L.S. Perera, have sought to lift off the historical "truths" which the mythic narrative was trying to convey in its own way.

If however this is the authenticity and quality of these so-called field-texts, it is best that they be kept away from contaminating the mainstream of a great tradition which such dubious concoctions as are readily forthcoming from glib-tongued village story-tellers for the serene joy and emotion of naive locals as much as ignorant foreign tourists.

As we saw, Obeysekere himself attributed the chronology of the Mahawamsa which he rightly considers "scrupulous", together with the work of the kings that are evidenced by archaeology, to temple-records. Yet on the other hand, he considers it

\footnotetext{
"Obeysekere, op.cit 584.

32 Cu/.39.25 One may recall Dutugemunu's clephant, Kandula, backing till he thought he had come to propitious terrain to stand the onslaught of Balluka's elephant. Though attributed to elephants, these may be as commanded by their drivers. Mounted on an elephant. the king was visible to his own ground troops as well as an inviting target for the enemy`s slings and arrows.

33 Obeysekere, p. 584-585.
} 
"wholly unwarranted" to treat the story-element which comes along with these as events that had actually occurred, even when they too derive from the same source.

By this time the Mahawamsa had seen the light of day. In fact Mahanama, its compiler, was believed to have been an uncle of Dhatusena and again that monk with whom he shared that chicken soup. Among the works of this monarch was also an out lay of thousands pieces of gold for the explication of the Dipavamsa (dipetum dipavamsam), work by which J.F. Fleet recognized that so-called Mahawamsa of the Ancients ${ }^{34}$.

With this growing sense of history over myth-history (though there now and again comes up something which may be symbolic, as for instance the two snake episodes in his youth) there is nothing improbable that takes place in the life of Dhatusena for doubt to be cast on his story in any event. What is obligatory with the science of historiography when it comes to myth-history is to strive and sift the historical from the mythical, not seek to substitute that which has come down from a near-contemporary antiquity with the hearsay tradition of a generation or two of persons who might even be its authors. To differ from the Mahawamsa calls for something more substantial than such "historical gossip".

MERLIN PERIS

${ }^{34}$ Cul.38.59 and on this, see Geiger op.cit p.p.35 n.2 ad loc. Geiger takes this to be a reading of the Dipavamsa perhaps with historical and legendary explanations, but not the composition of so voluminous a work as Mahawamsa of the Ancients. So with this would inevitably have evolved a more serious sense of historiography. 